\title{
Liquid Mn Penetration and Reaction Treatment of Plasma-sprayed $\mathrm{Al}_{2} \mathrm{O}_{3}$ Coating
}

\section{Akira OHMORI, Zhan ZHOU and Katsunori INOUE}

Research Center for High Energy Surface Processing, Welding Research Institute, Osaka University, Mihogaoka, Ibaraki, Osaka-fu, 567 Japan.

(Received on April 15, 1993; accepted in final form on July 15, 1993)

The penetration phenomena of liquid $\mathrm{Mn}$ to porous $\mathrm{Al}_{2} \mathrm{O}_{3}$ coating plasma-sprayed on $\mathrm{SS} 400$ steel substrate was studied by heating at $1573 \mathrm{~K}$ in vacuum atmosphere. Moreover, the possibility of improving the $\mathrm{Al}_{2} \mathrm{O}_{3}$ coating properties was examined. The formation of $\mathrm{MnAl}_{2} \mathrm{O}_{4}$ was clearly recognized in the connected porosity of $\mathrm{Al}_{2} \mathrm{O}_{3}$ coating penetrated with liquid $\mathrm{Mn}$. It was revealed that the hardness and the fracture stress of the composite coating consisted of $\mathrm{Al}_{2} \mathrm{O}_{3}$ and $\mathrm{MnAl}_{2} \mathrm{O}_{4}$ without porosities after heat-treatment with $\mathrm{Mn}$ increased greatly compared with as-sprayed $\mathrm{Al}_{2} \mathrm{O}_{3}$ coating.

KEY WORDS: $\mathrm{Al}_{2} \mathrm{O}_{3}$ coating; $\mathrm{MnAl}_{2} \mathrm{O}_{4}$; liquid manganese; penetration; plasma-spraying; heat-treatment; SS400 steel.

\section{Introduction}

Plasma-sprayed ceramic coatings have been widely applied in many industrial fields because of an excellent wear, erosion, heat resistance, and corrosion resistance which ceramics possess themselves. $\mathrm{Al}_{2} \mathrm{O}_{3}$ coatings plasma-sprayed are well known as wear and insulation coatings. ${ }^{1)}$ However, because of existence of the connected porosity in ceramics coatings, the properties of ceramic coatings, such as their resistance to wear, corrosion, erosion, high temperature oxidation etc. are reduced. In order to improve the properties of coatings, various methods have been reported, ${ }^{1-3)}$ such as sealing with resin and chromium trioxide, electro-plating of metal etc. In order to make greater use of $\mathrm{Al}_{2} \mathrm{O}_{3}$ coatings at high temperature, it is necessary to develop more effective post-treatment methods.

In this study, the penetration of liquid $\mathrm{Mn}$ into connected porosity in $\mathrm{Al}_{2} \mathrm{O}_{3}$ coatings was utilized to form a dense and composite coating in order to improve the properties of the coatings. The penetration behavior of liquid $\mathrm{Mn}$, and the improving the mechanical properties of $\mathrm{Al}_{2} \mathrm{O}_{3}$ coatings were examined.

\section{Materials and Experimental Procedures}

\subsection{Materials}

The substrate was a SS400 mild steel plate with $15 \mathrm{~mm} \times 15 \mathrm{~mm} \times 3 \mathrm{~mm}$. The surface was grit blasted before spraying. Commercially available $\mathrm{Al}_{2} \mathrm{O}_{3}$ powder was used as the plasma spray powder. The mean particle size of the powder was $10-44 \mu \mathrm{m}$. Plasma spraying was carried out in the air and $\mathrm{Al}_{2} \mathrm{O}_{3}$ coating with a thickness of $150-200 \mu \mathrm{m}$ was produced by employing the spraying conditions shown in Table 1. Metals for the penetration treatment were of purity $99.99 \mathrm{wt} \% \mathrm{Mn}, \mathrm{Ni}$ and $\mathrm{Cu}$ plate, of about 3-5 g. Sintered alumina plate of purity $99.7 \mathrm{wt} \%$ in $15 \mathrm{~mm}$ diameter and $3 \mathrm{~mm}$ thickness for the reaction with liquid Mn was used. These assembly were degreased

Table 1. Plasma spraying condition for $\mathrm{Al}_{2} \mathrm{O}_{3}$ coating.

\begin{tabular}{lll}
\hline Spray apparatus & & Plasmadyne (Mach 1) \\
\hline Plasma gas (Ar) & Pressure & $7 \mathrm{~kg} \cdot \mathrm{cm}^{-2}$ \\
& Flow rate & $47 \mathrm{l} \cdot \mathrm{min}^{-1}$ \\
Auxiliary gas (He) & Pressure & $4.2 \mathrm{~kg} \cdot \mathrm{cm}^{-2}$ \\
& Flow rate & $5.7 l \cdot \mathrm{min}^{-1}$ \\
Powder carrier gas (Ar) & Pressure & $5.6 \mathrm{~kg} \cdot \mathrm{cm}^{-2}$ \\
& Flow rate & $38 l \cdot \mathrm{min}^{-1}$ \\
Plasma power & & $27.2 \mathrm{~kW}$ \\
Spray current & & $800 \mathrm{~A}$ \\
Plasma distance & & $100 \mathrm{~mm}$ \\
Hopper setting & & $6.3 \mathrm{M} \cdot \mathrm{min}^{-1}$ \\
Cooling air pressure & & $2.0 \mathrm{~kg} \cdot \mathrm{cm}^{-2}$ \\
\hline
\end{tabular}

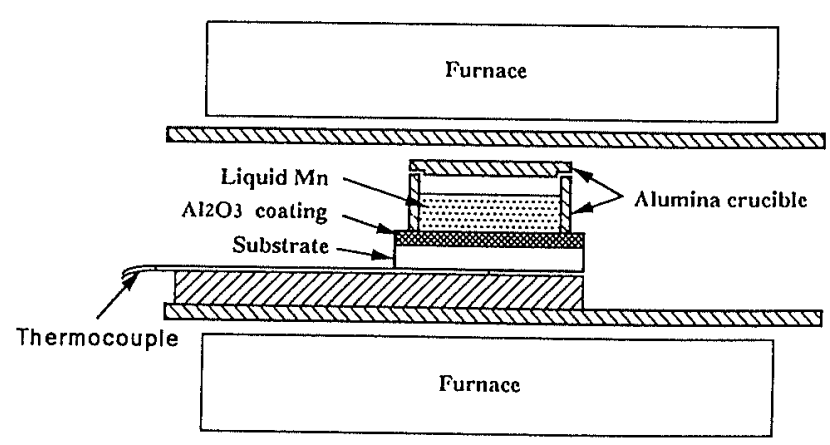

Fig. 1. Schematic diagram of the experimental apparatus for liquid $\mathrm{Mn}$ penetration treatment. 

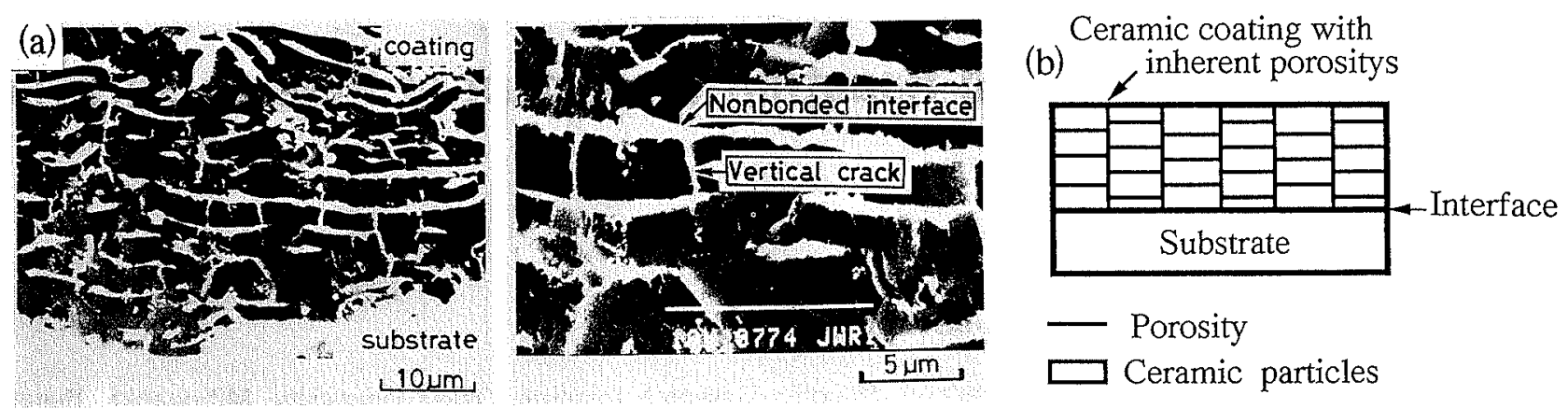

Fig. 2. (a) Typical SEM microstructure of a copper-electroplated $\mathrm{Al}_{2} \mathrm{O}_{3}$ coating. White strings are copper and represent vertical cracks in individual lamella and non-bonded interfaces between flattened particles, and (b) schematic illustration of cross section of ceramic coating.

in acetone with an ultrasonic bath, before the heattreatment.

\subsection{Method of Liquid Mn Penetration Treatment}

Figure 1 shows a schematic diagram of the experimental apparatus of liquid metal penetration treatment. The metals of the definite quantity were contacted with the surface of $\mathrm{Al}_{2} \mathrm{O}_{3}$ coatings and was heated under vacuum of $1.33 \times 10^{-1}$ or $1.33 \times 10^{-3} \mathrm{~Pa}$ at $1573 \mathrm{~K}$ at the heating rate of $50 \mathrm{~K} / \mathrm{min}$. After keeping at the appointed temperature, the assembly was cooled in the furnace at the cooling rate of $1.5 \mathrm{~K} / \mathrm{min}$. Alumina crucible with $13 \mathrm{~mm}$ inside diameter and $\mathrm{Mn}$ was set on the surface of $\mathrm{Al}_{2} \mathrm{O}_{3}$ coating.

\subsection{Method of Analysis and Evaluation of Coating}

Cross-sections of sprayed test pieces and heat-treatment test pieces were examined by scanning electron microscopy (SEM), and changes in elemental composition of the cross-section of coating and in crystal structure of the coating were studied by mean of an electron probe micro analyzer (EPMA) and X-ray diffraction analyzer (XRD) respectively. The micropores of coating, the distribution and existence of porosity in coating were appreciated by mean of observing copper deposited in the coating by electroplating. ${ }^{3)}$ Fracture stress of the coating and sintered alumina were the maximum tensile stress at inflection point from the relation between applied load and friction force for coating or sintered alumina through scratch test. ${ }^{4)}$

\section{Experimental Results and Discussions}

\subsection{Micropores of $\mathrm{Al}_{2} \mathrm{O}_{3}$ Coating}

Plasma-sprayed ceramics coatings have a layer structure formed by the deposition of flattened, rapidly solidified particles. The connected porosities which were composed of micropores, a non-bonded area between ceramic lamellae and microcracks in individual flattened particles exist in the coating. Figure 2(a) shows typical SEM microstructure of a cross-section of a copperelectroplated $\mathrm{Al}_{2} \mathrm{O}_{3}$ coating. The distribution of the connected porosities, non-bonded area between flattened particles and the vertical crack in individual flattened particles in the coating are observed clearly by the deposited copper of white area. It has been reported that the width of these vertical direction and horizontal

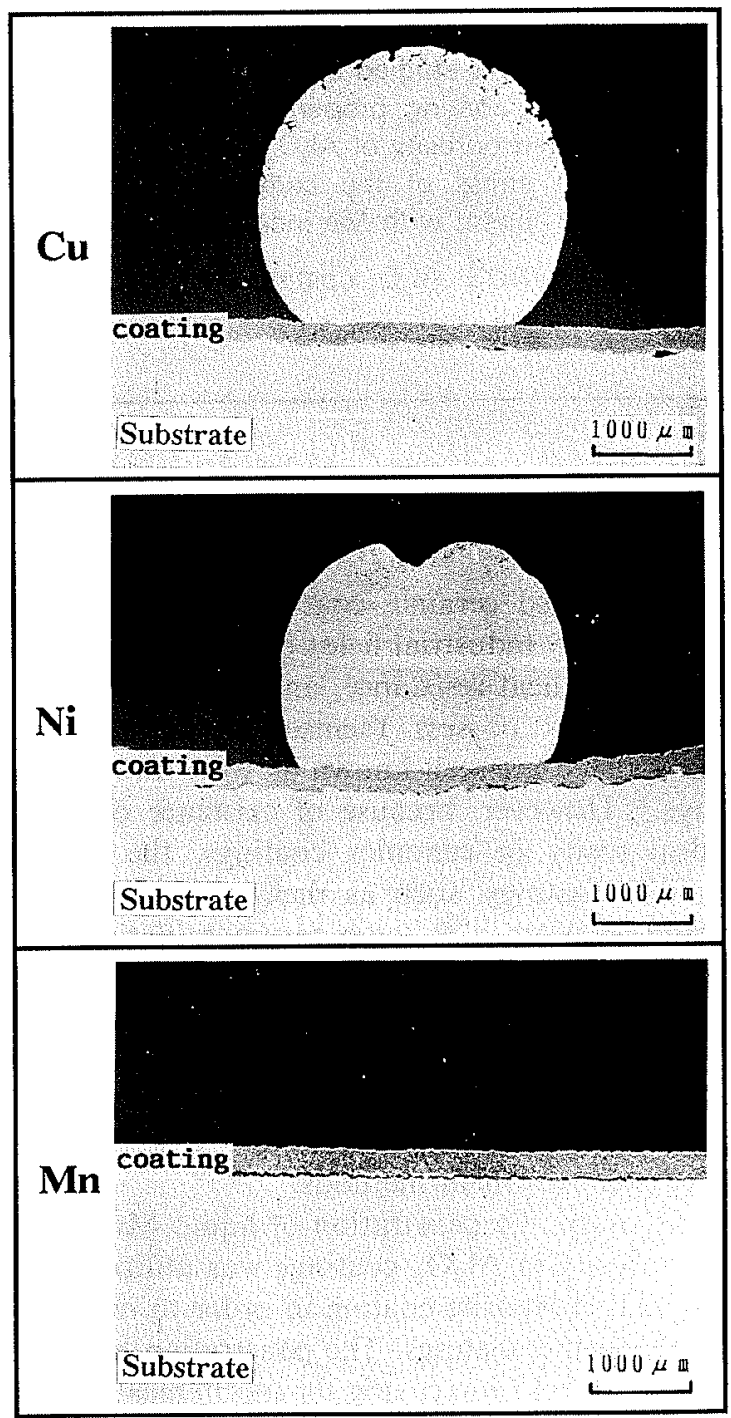

Fig. 3. Shape of various metals on $\mathrm{Al}_{2} \mathrm{O}_{3}$ coating surface after heat-treatment.

direction of porosities are about $0.16-0.19 \mu \mathrm{m}$ and $0.25-0.38 \mu \mathrm{m} .{ }^{5)}$ Schematic diagram of the distribution of the connected porosities from coating surface to the interface between coating and substrate is shown like network in Figure 2(b).

\subsection{Penetration Behavior of Liquid Mn into Connected Prosities in $\mathrm{Al}_{2} \mathrm{O}_{3}$ Coating}

In order to certify the penetration of liquid $\mathrm{Mn}$ into 

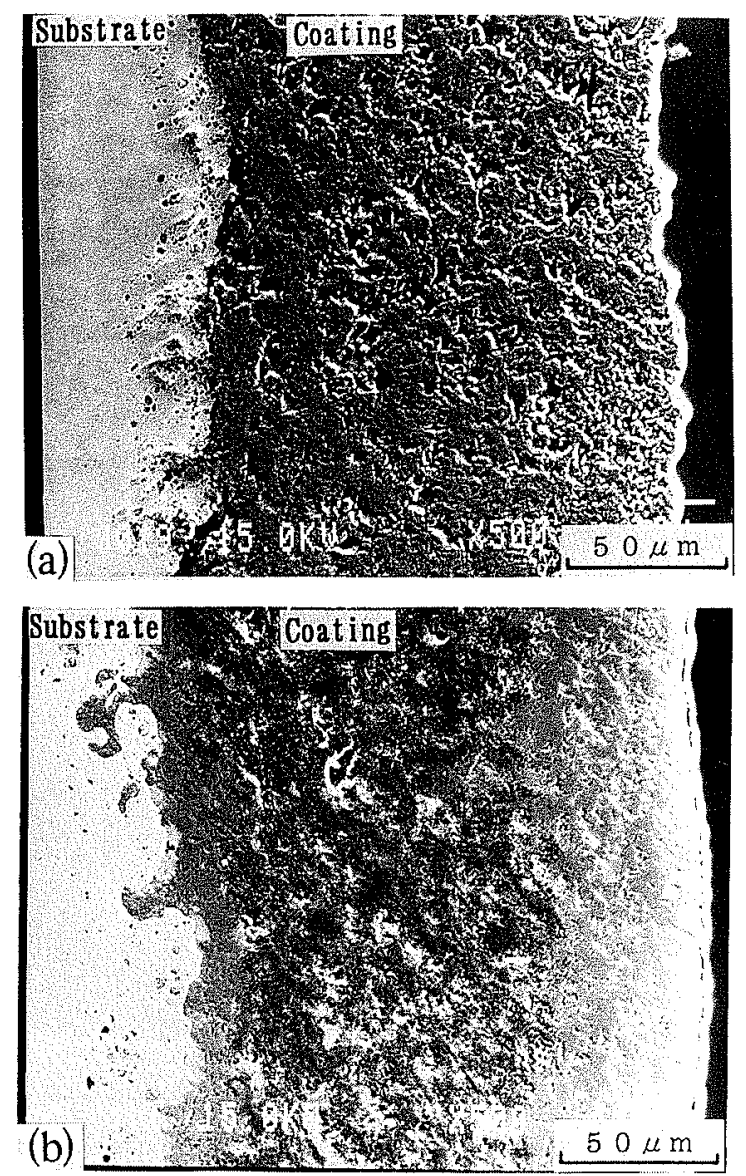

Fig. 4. $\mathrm{SEM}$ microstructures of $\mathrm{Al}_{2} \mathrm{O}_{3}$ coatings heat-treated with $\mathrm{Mn}$ at $1573 \mathrm{~K}$ in $1.33 \times 10^{-3} \mathrm{~Pa}$ : (a) for $0.9 \mathrm{ks}$; (b) for $3.6 \mathrm{ks}$.

$\mathrm{Al}_{2} \mathrm{O}_{3}$ coating, metals such as $\mathrm{Cu}, \mathrm{Ni}, \mathrm{Mn}$ was set on $\mathrm{Al}_{2} \mathrm{O}_{3}$ coating and heated for $0.3 \mathrm{ks}$ at temperature of $50 \mathrm{~K}$ over melting point of each metal in vacuum. Figure 3 shows the shape of various metals on $\mathrm{Al}_{2} \mathrm{O}_{3}$ coating after heat-treatment. The apparent contact angle of $\mathrm{Cu}$, $\mathrm{Ni}$ and $\mathrm{Mn}$ were about $140^{\circ}, 115^{\circ}$ and $0^{\circ}$, respectively. It was recognized that the penetration of liquid metal into $\mathrm{Al}_{2} \mathrm{O}_{3}$ coating occurred with $\mathrm{Mn}$ on $\mathrm{Al}_{2} \mathrm{O}_{3}$ coating. However, $\mathrm{Cu}$ and $\mathrm{Ni}$ were not penetrated into $\mathrm{Al}_{2} \mathrm{O}_{3}$ coating. Figure 4 shows the SEM microstructure of cross-section of $\mathrm{Al}_{2} \mathrm{O}_{3}$ coating after heat-treatment with $\mathrm{Mn}$ for 0.9 and $3.6 \mathrm{ks}$ at $1573 \mathrm{~K}$ in $1.33 \times 10^{-3} \mathrm{~Pa}$, respectively. In the case of $0.9 \mathrm{ks}$, it was recognized that the thin dense layer of about $2-5 \mu \mathrm{m}$ was formed on the surface of coating, but in the inside of coating the densification did not occur and the microstructure is like that of as-sprayed $\mathrm{Al}_{2} \mathrm{O}_{3}$ coating. In the case of $3.6 \mathrm{ks}$ compared with that of $0.9 \mathrm{ks}$, a thick dense layers were formed on the surface of coating and at interface between coating and SS400 steel substrate. The defects of porosity etc. also disappeared in middle area of coating. Figure 5 shows XRD results of surface layer and inside of the $\mathrm{Al}_{2} \mathrm{O}_{3}$ coatings shown in Figs. 4(a) and $\mathbf{4 ( b )}$. Existence of a little amount of $\mathrm{MnAl}_{2} \mathrm{O}_{4}$ was recognized on the surface of coating in the case of $0.9 \mathrm{ks}$ and $\alpha-\mathrm{Al}_{2} \mathrm{O}_{3}$ is main phase. In inside of same coating, existence of a little amount of $\alpha$-Mn was recognized and intensity ratio of $\mathrm{MnAl}_{2} \mathrm{O}_{3} / \alpha-\mathrm{Al}_{2} \mathrm{O}_{3}$ is smaller than that of the surface.

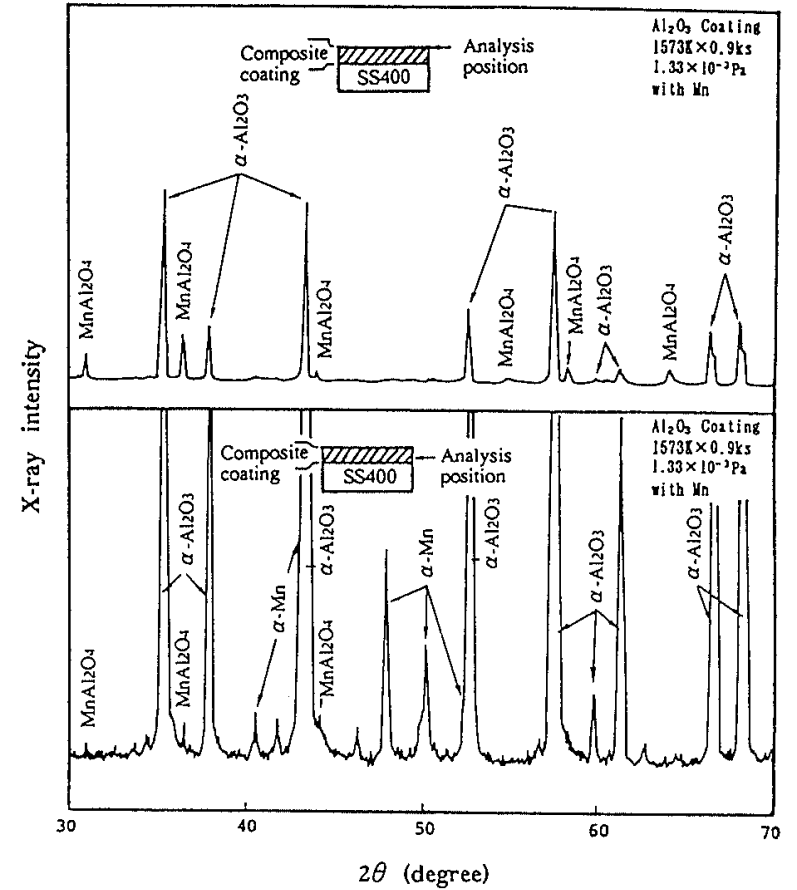

(a)

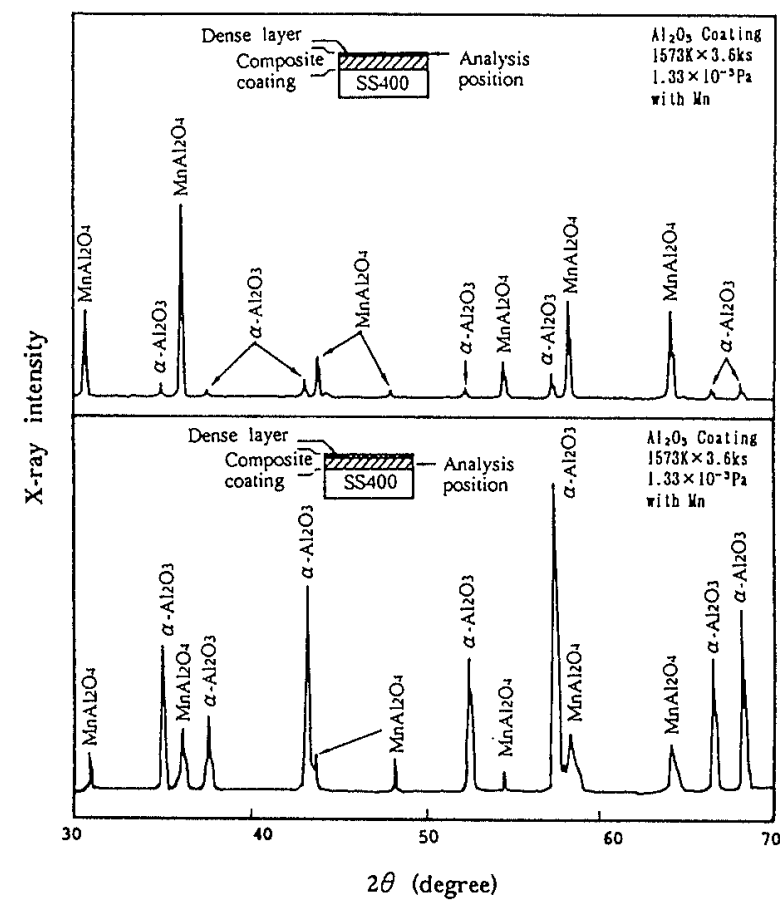

(b)

Fig. 5. XRD results of surface and inside of $\mathrm{Al}_{2} \mathrm{O}_{3}$ coatings heat-treated with $\mathrm{Mn}$ : (a) for $0.9 \mathrm{ks}$; (b) for $3.6 \mathrm{ks}$

Compare with that of $0.9 \mathrm{ks}$, the $\mathrm{MnAl}_{2} \mathrm{O}_{4}$ on the new dense surface layer of the coating heat-treated with $\mathrm{Mn}$ for $3.6 \mathrm{ks}$ was markedly increased and became composite phase composed of $\mathrm{MnAl}_{2} \mathrm{O}_{4}$ as main phase and $\mathrm{Al}_{2} \mathrm{O}_{3}$. The inside of the coating, where the $\mathrm{MnAl}_{2} \mathrm{O}_{4}$ phase was increased with disappearance of $\alpha-\mathrm{Mn}$ compare with that of inside of coating heat-treated for $0.9 \mathrm{ks}$, was composed of $\mathrm{Al}_{2} \mathrm{O}_{3}$ phase as main phase and $\mathrm{MnAl}_{2} \mathrm{O}_{4}$ spinel. It may be considered that $\mathrm{MnAl}_{2} \mathrm{O}_{4}$ was formed by reaction 

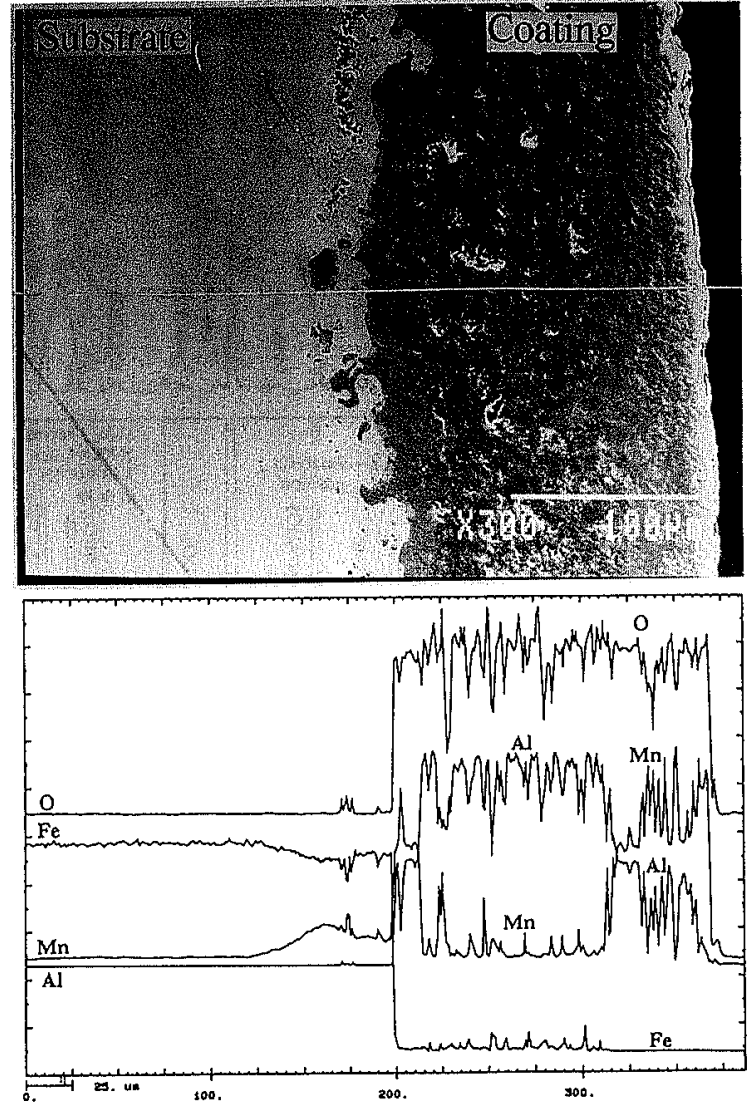

Fig. 6. SEM image and EPMA line analysis results of cross-section of $\mathrm{Al}_{2} \mathrm{O}_{3}$ coating heat-treated with $\mathrm{Mn}$ for $3.6 \mathrm{ks}$ at $1573 \mathrm{~K}$ in $1.33 \times 10^{-3} \mathrm{~Pa}$.

of liquid $\mathrm{Mn}$ dissolved oxygen in vacuum atmosphere and $\mathrm{Al}_{2} \mathrm{O}_{3}$. Figure 6 shows the microstructure and EPMA line analysis results of cross-section of $\mathrm{Al}_{2} \mathrm{O}_{3}$ coating shown in Fig. 4(b). From this EPMA analysis, Mn concentration in dense layers on the surface and at the interface of the coating is higher than that of the inside of coating, and the intensity ratio between $\mathrm{Mn}$ and $\mathrm{Al}$ in both layers is almost same. Therefore, it may be considered that the dense layer of the interface is also composite phase composed of $\mathrm{MnAl}_{2} \mathrm{O}_{4}$ as main phase and $\mathrm{Al}_{2} \mathrm{O}_{3}$ phase such as that of dense layer of the surface.

In the inside of the coating, almost uniform alternate change of concentration of $\mathrm{Mn}$ and $\mathrm{Al}$ are recognized and narrow peaks of $\mathrm{Mn}$ existed between broad peaks of $\mathrm{Al}$ which shows the deposited $\mathrm{Al}_{2} \mathrm{O}_{3}$ particle part. From the result, it is considered that $\mathrm{MnAl}_{2} \mathrm{O}_{4}$ spinel exists among the $\mathrm{Al}_{2} \mathrm{O}_{3}$ particles deposited. Moreover, the constant $\mathrm{Mn}$ concentration gradient from the coating side to SS400 steel substrate is recognized and $\mathrm{Mn}-\mathrm{Fe}$ alloy layer with about $70 \mu \mathrm{m}$ was seen in the substrate side.

From these results, the liquid $\mathrm{Mn}$ could penetrate easily into inside of $\mathrm{Al}_{2} \mathrm{O}_{3}$ coating until the interface between the coating and substrate through the connected porosities of coating in short time. The formation of $\mathrm{MnAl}_{2} \mathrm{O}_{4}$ by the reaction of $\mathrm{Mn}(\mathrm{O})$ and $\mathrm{Al}_{2} \mathrm{O}_{3}$ particle in the connected porosities increased with increase of heat time. The porosities in $\mathrm{Al}_{2} \mathrm{O}_{3}$ coating were filled with $\mathrm{MnAl}_{2} \mathrm{O}_{4}$ spinel formed around $\mathrm{Al}_{2} \mathrm{O}_{3}$ deposited particles in the inside of $\mathrm{Al}_{2} \mathrm{O}_{3}$ coating. On the other
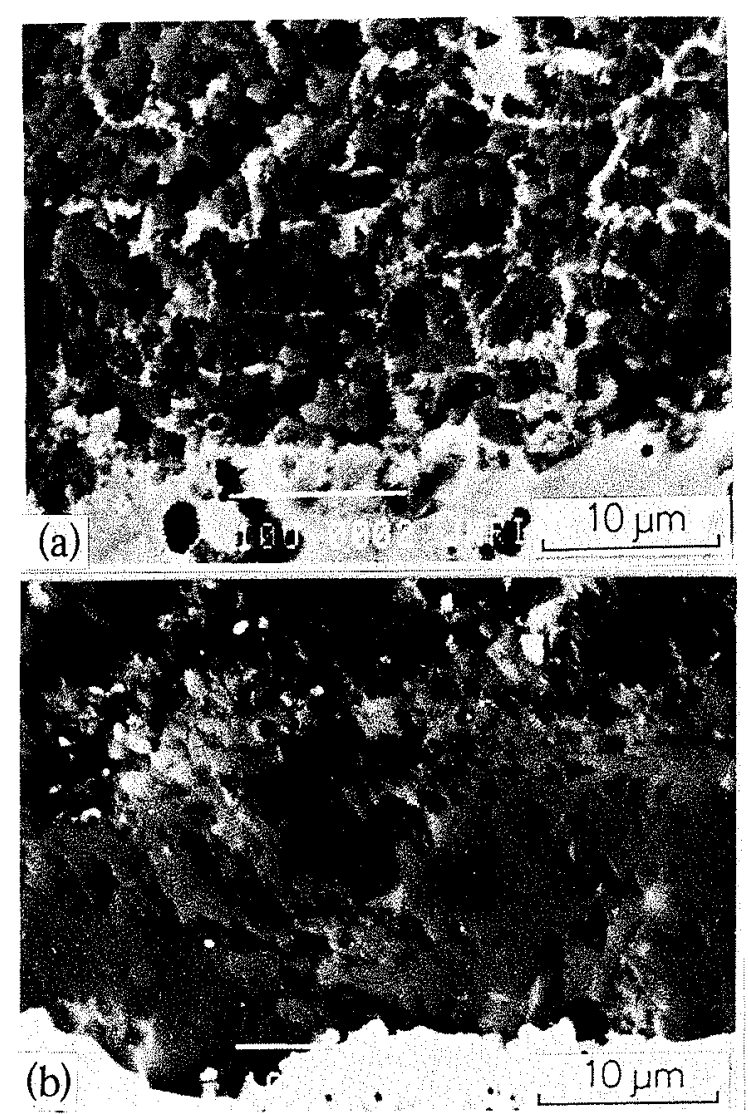

Fig. 7. SEM micrographs of cross-section of copper-electroplated $\mathrm{Al}_{2} \mathrm{O}_{3}$ coatings heat-treated for $3.6 \mathrm{ks}$ at $1573 \mathrm{~K}$ in $1.33 \times 10^{-3} \mathrm{~Pa}$ : (a) $\mathrm{Al}_{2} \mathrm{O}_{3}$ coating heattreated without $\mathrm{Mn}$; (b) $\mathrm{Al}_{2} \mathrm{O}_{3}$ coating heat-treated with $\mathrm{Mn}$.

hand, thick layer composed of $\mathrm{MnAl}_{2} \mathrm{O}_{4}$ as main phase was formed on the surface of $\mathrm{Al}_{2} \mathrm{O}_{3}$ coating due to supply of a large amount of liquid $\mathrm{Mn}(\mathrm{O})$. Figure 7 shows SEM images of cross-section of copper-electroplated $\mathrm{Al}_{2} \mathrm{O}_{3}$ coatings heat-treated with and without $\mathrm{Mn}$ for $3.6 \mathrm{ks}$ at $1573 \mathrm{~K}$ in vacuum. As shown in this figure, the deposited copper was not found without the connected porosities in the inside of $\mathrm{Al}_{2} \mathrm{O}_{3}$ coating heat-treated with $\mathrm{Mn}$.

\subsection{Reaction of $\mathrm{Al}_{2} \mathrm{O}_{3}$ Particle and Liquid Mn}

Figure 8 shows SEM image and EPMA line analysis results of cross-section of sintered $\mathrm{Al}_{2} \mathrm{O}_{3}$ plate heattreated with $\mathrm{Mn}$ for $3.6 \mathrm{ks}$ at $1573 \mathrm{~K}$ in $1.33 \times 10^{-3} \mathrm{~Pa}$. Figure 9 shows XRD analysis result of the surface of sintered $\mathrm{Al}_{2} \mathrm{O}_{3}$ heat-treated with $\mathrm{Mn}$ on the same conditions as shown in Fig. 8. From these results, the formation reaction of $\mathrm{MnAl}_{2} \mathrm{O}_{4}$ between sintered $\mathrm{Al}_{2} \mathrm{O}_{3}$ and liquid $\mathrm{Mn}$ occurred as shown in the case of $\mathrm{Al}_{2} \mathrm{O}_{3}$ coating. A dense reaction layer formed newly on the surface of sintered $\mathrm{Al}_{2} \mathrm{O}_{3}$ plate.

As mentioned above, $\mathrm{Mn}$ reacted with $\mathrm{Al}_{2} \mathrm{O}_{3}$ particle to give $\mathrm{MnAl}_{2} \mathrm{O}_{4}$ during $\mathrm{Mn}$ penetration in $\mathrm{Al}_{2} \mathrm{O}_{3}$ coating. Therefore, it must be useful to consider a reaction between $\mathrm{Mn}$ and $\mathrm{Al}_{2} \mathrm{O}_{3}$ during heat-treatment with $\mathrm{Mn}$ at $1573 \mathrm{~K}$ in vacuum atmosphere. On the reaction.

$\mathrm{Al}_{2} \mathrm{O}_{3}(\mathrm{~s})+3 / 4 \mathrm{Mn}(1)=3 / 4 \mathrm{MnAl}_{2} \mathrm{O}_{4}(\mathrm{~s})+1 / 2 \mathrm{Al}(1) \ldots$ 

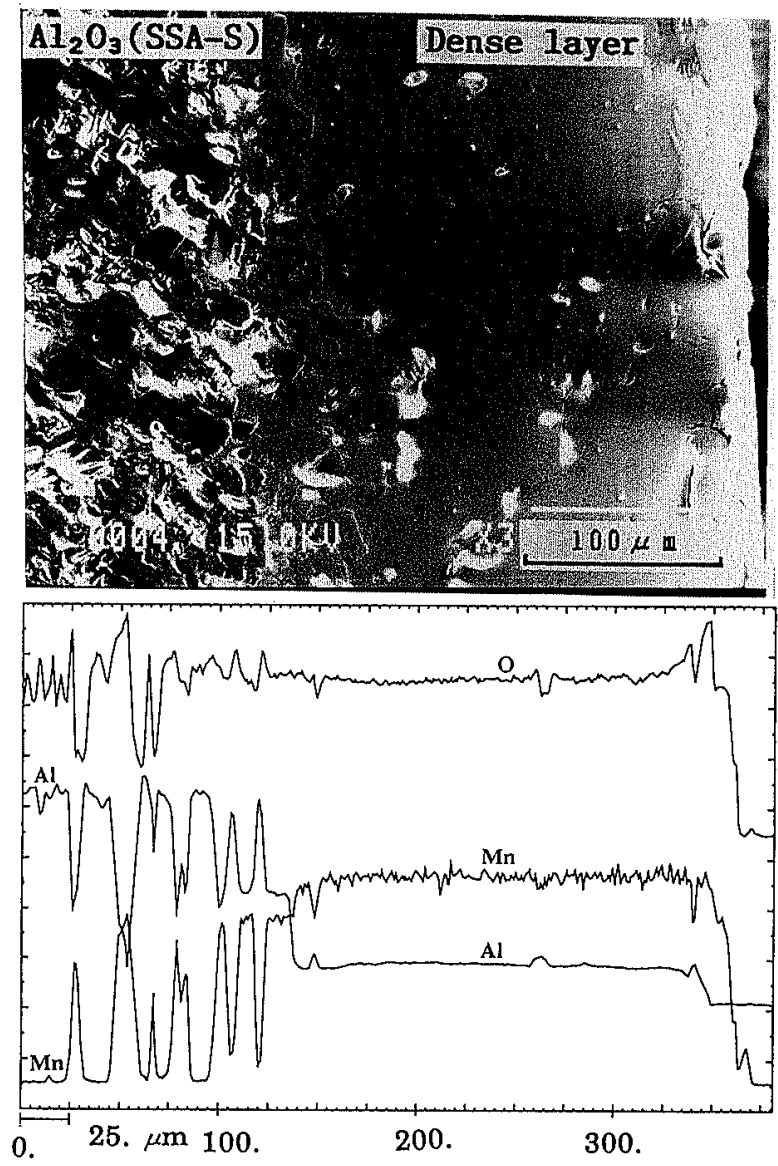

Fig. 8. SEM image and EPMA line analysis results of cross-section of sintered alumina plate heat-treated with $\mathrm{Mn}$ for $3.6 \mathrm{ks}$ at $1573 \mathrm{~K}$ in $1.33 \times 10^{-3} \mathrm{~Pa}$.

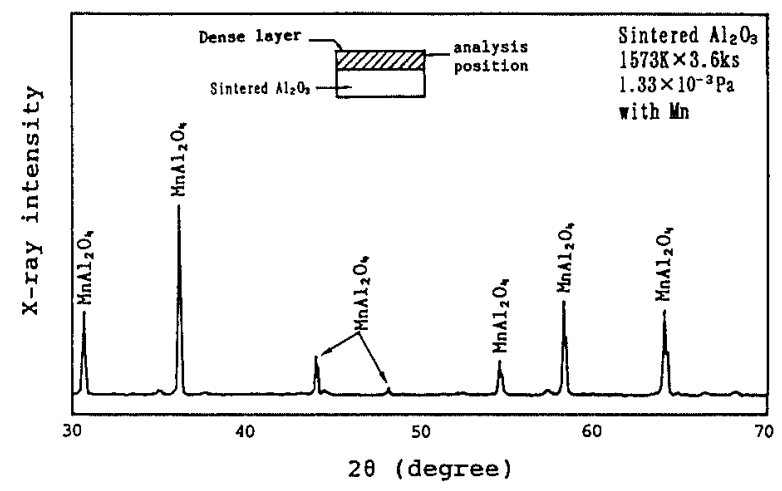

Fig. 9. XRD result of surface of sintered alumina heat-treated with $\mathrm{Mn}$.

$$
\Delta G^{\circ}=92458.8-22.275 T \quad \mathrm{~J} \mathrm{~mol}^{-1}
$$

The direct reaction between $\mathrm{Mn}$ and $\mathrm{Al}_{2} \mathrm{O}_{3}$ at $1573 \mathrm{~K}$ could not occur in thermodynamics, since the Gibbs free energy is possitive $\left(\Delta G^{\circ}=+57420 \mathrm{~J} / \mathrm{mol}\right)$. However, in this study the formation of $\mathrm{MnAl}_{2} \mathrm{O}_{4}$ was seen. It may be considered that oxygen $\left(\mathrm{O}_{2}\right)$ contained in vacuum atmosphere dissolved into liquid $\mathrm{Mn}$ and participated in the formation reaction of $\mathrm{MnAl}_{2} \mathrm{O}_{4}$ between liquid $\mathrm{Mn}$ and $\mathrm{Al}_{2} \mathrm{O}_{3}$.

For the reaction and Gibbs energy of the formation of $\mathrm{MnAl}_{2} \mathrm{O}_{4}$.

$$
\mathrm{Al}_{2} \mathrm{O}_{3}(\mathrm{~s})+\mathrm{Mn}(1)+1 / 2 \mathrm{O}_{2}=\mathrm{MnAl}_{2} \mathrm{O}_{4}(\mathrm{~s})
$$

$$
\Delta G^{\circ}=-439970+90.93 T \quad \mathrm{~J} \mathrm{~mol}^{-1}
$$

In the case, it is possible that the formation reaction of $\mathrm{MnAl}_{2} \mathrm{O}_{4}$ occurs because $\Delta G^{\circ}$ is $-296973 \mathrm{~J} / \mathrm{mol}$ at $1573 \mathrm{~K}$.

Effect of pressure for heat-treatment on $\mathrm{Mn}$ penetration into $\mathrm{Al}_{2} \mathrm{O}_{3}$ coatings was examined. Figure 10 shows SEM images and image analyses of $\mathrm{Mn}, \mathrm{Al}$ and $\mathrm{O}$ for $\mathrm{Al}_{2} \mathrm{O}_{3}$ coatings heat-treated with $\mathrm{Mn}$ for $3.6 \mathrm{ks}$ at $1573 \mathrm{~K}$ in pressures of $1.33 \times 10^{-1}$ and $1.33 \times 10^{-3} \mathrm{~Pa}$, respectively. In the case of heat-treatment in a highly evacuated condition. $\mathrm{Mn}$ is distributed like network over inside of $\mathrm{Al}_{2} \mathrm{O}_{3}$ coatings. Moreover, thick $\mathrm{Mn}$ rich layer is seen on the surface of $\mathrm{Al}_{2} \mathrm{O}_{3}$ coating and at the interface between $\mathrm{Al}_{2} \mathrm{O}_{3}$ coating and $\mathrm{SS} 400$ substrate. However, in a low evacuated condition, a remarkable existence of $\mathrm{Mn}$ in the inside of $\mathrm{Al}_{2} \mathrm{O}_{3}$ coating is scarcely seen, although thin $\mathrm{Mn}$ rich layer exists on the surface of coating and at the interface. It may be considered that oxygen amount dissolved in liquid $\mathrm{Mn}$ in a low evacuated condition is greater than that in a highly evacuated condition. So that liquid $\mathrm{Mn}$ contained a greater amount of oxygen reacts more easily and quickly with $\mathrm{Al}_{2} \mathrm{O}_{3}$ particle to give much $\mathrm{MnAl}_{2} \mathrm{O}_{4}$ on the surface of $\mathrm{Al}_{2} \mathrm{O}_{3}$ coating. Because of formation of a great amount of $\mathrm{MnAl}_{2} \mathrm{O}_{4}$ on the surface of coating, the penetration of liquid $\mathrm{Mn}$ into the inside of coating may be suppressed during heat-treatment with $\mathrm{Mn}$ in the low evacuated condition.

\subsection{Mechanical Properties of $\mathrm{Al}_{2} \mathrm{O}_{3}$ Coating after Heat-treatment with $\mathrm{Mn}$}

Figure 11 shows the Vickers hardness distribution of cross-section of $\mathrm{Al}_{2} \mathrm{O}_{3}$ coatings heat-treated with $\mathrm{Mn}$ at $1573 \mathrm{~K}$ in $1.33 \times 10^{-3} \mathrm{~Pa}$, as-sprayed $\mathrm{Al}_{2} \mathrm{O}_{3}$ coating and sintered $\mathrm{Al}_{2} \mathrm{O}_{3}$. From the results, the hardness of $\mathrm{Al}_{2} \mathrm{O}_{3}-\mathrm{MnAl}_{2} \mathrm{O}_{4}$ composite coating after heat-treatment with $\mathrm{Mn}$ was increased remarkably, compared with about $700-800 \mathrm{Hv}$, of as-sprayed $\mathrm{Al}_{2} \mathrm{O}_{3}$ coating. Hardness of cross-section of $\mathrm{Al}_{2} \mathrm{O}_{3}$ composite coating in the case of heat-treatment with $\mathrm{Mn}$ for $10.8 \mathrm{ks}$ reached $1600 \mathrm{Hv}$, it is greater than about $1450 \mathrm{Hv}$ of sintered $\mathrm{Al}_{2} \mathrm{O}_{3}$.

These results can be considered that as-sprayed $\mathrm{Al}_{2} \mathrm{O}_{3}$ coating with connected porosities became dense and the bond among deposited $\mathrm{Al}_{2} \mathrm{O}_{3}$ particles strengthened. Because the connected porosities in coating were penetrated with liquid $\mathrm{Mn}(\mathrm{O})$ and were filled up with $\mathrm{MnAl}_{2} \mathrm{O}_{4}$ formed by the reaction of $\mathrm{Al}_{2} \mathrm{O}_{3}$ particle and liquid $\mathrm{Mn}(\mathrm{O})$.

The fracture stress of the $\mathrm{Al}_{2} \mathrm{O}_{3}$ coatings etc. calculated as follows. The relation between applied load and friction force was obtained from scratch test for surface of the test pieces polished, and the applied loads of $\mathrm{Al}_{2} \mathrm{O}_{3}$ coating heat-treated with $\mathrm{Mn}$ for $3.6 \mathrm{ks}$ at $1573 \mathrm{~K}$, as-sprayed $\mathrm{Al}_{2} \mathrm{O}_{3}$ coating and sintered $\mathrm{Al}_{2} \mathrm{O}_{3}$ were 3.1, 1.2 and $2.2 \mathrm{~N}$ as the inflection point respectively as shown in Fig. 12. The maximum tensile stress can be obtained as follows:

$$
\sigma=\sigma_{\circ}\left(\frac{1-2 \nu}{2}\right)(1+A \cdot f)
$$



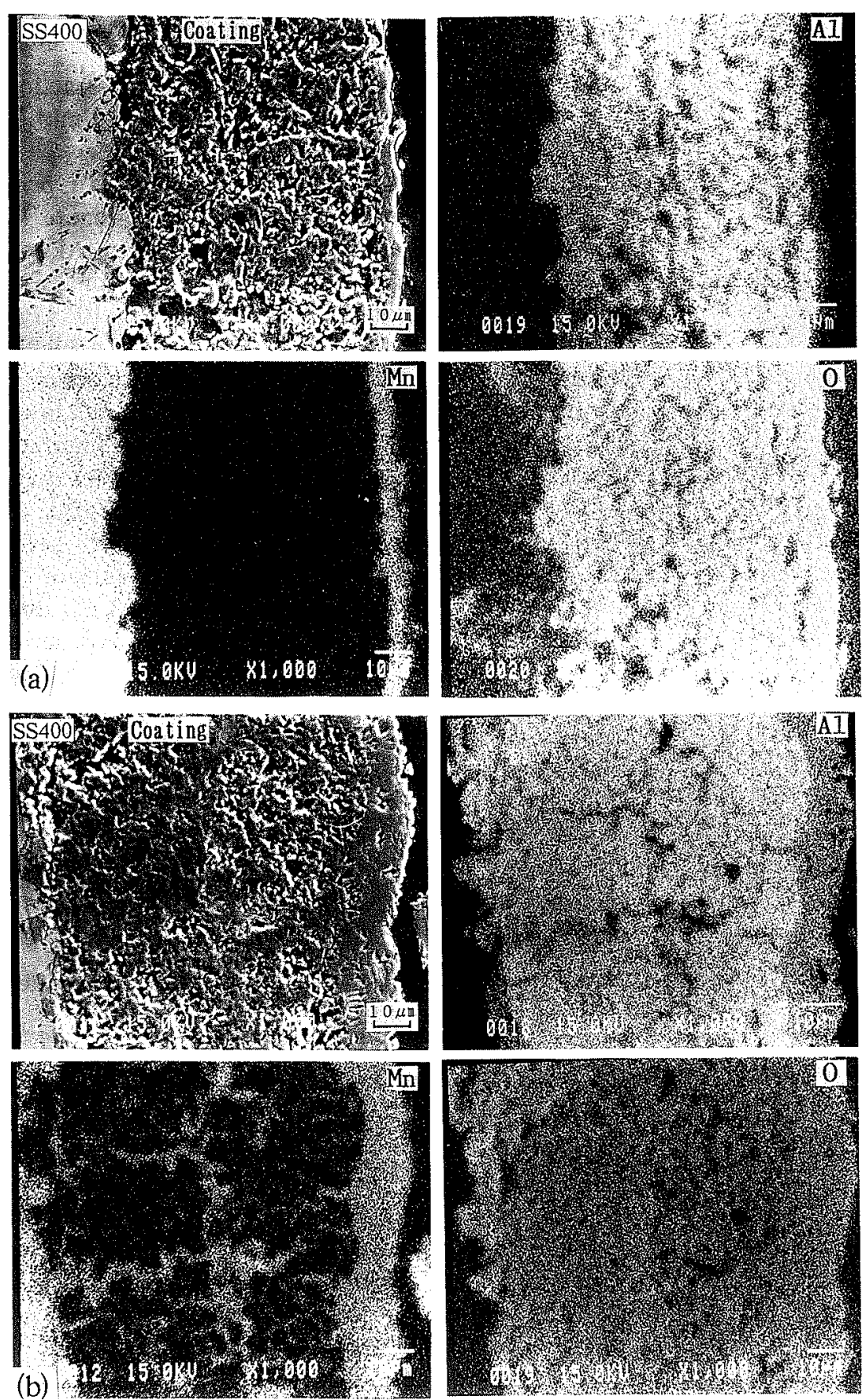

Fig. 10.

EPMA image for $\mathrm{Al}_{2} \mathrm{O}_{3}$ coating heat-treated with Mn for $3.6 \mathrm{ks}$ at $1573 \mathrm{~K}$ (a) in $1.33 \times 10^{-1} \mathrm{~Pa}$; (b) in $1.33 \times 10^{-3} \mathrm{~Pa}$.

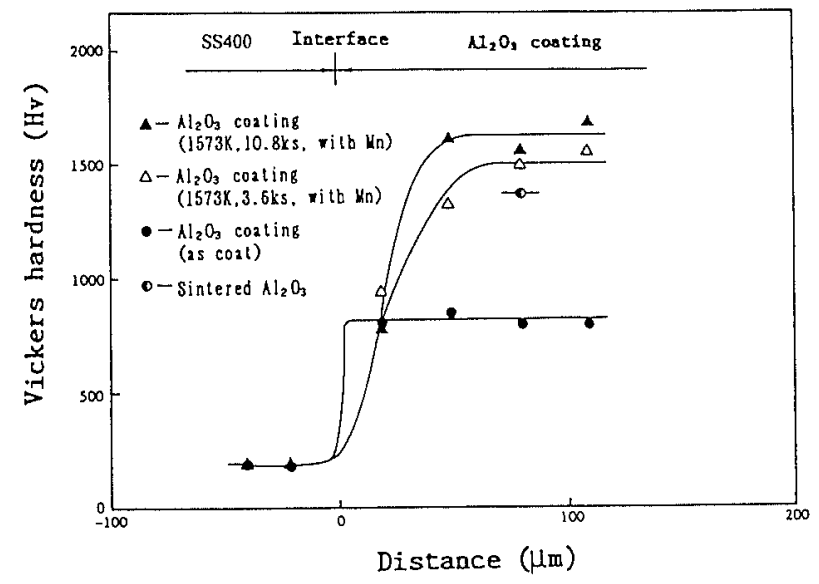

Fig. 11. Vickers hardness distribution of cross-section of $\mathrm{Al}_{2} \mathrm{O}_{3}$ coatings as-sprayed, heat-treated with $\mathrm{Mn}$ and sintered alumina.

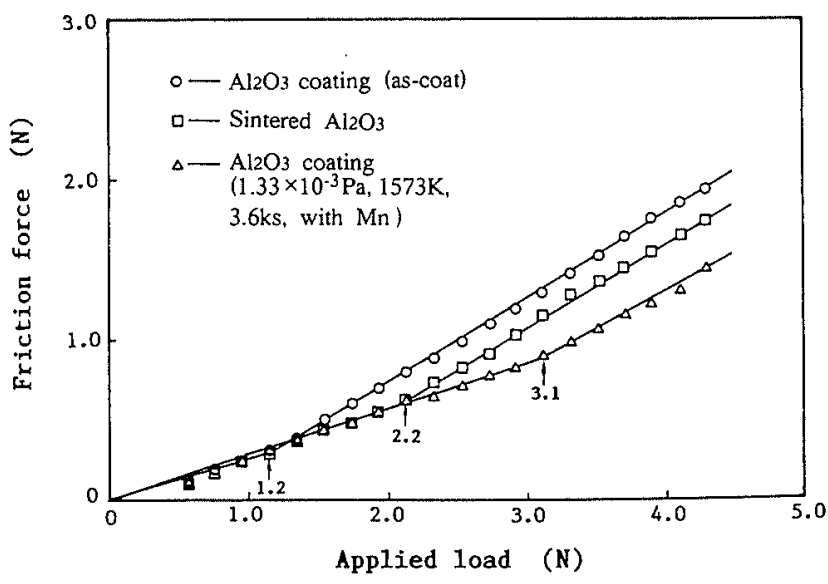

Fig. 12. Relation between applied load and friction force for $\mathrm{Al}_{2} \mathrm{O}_{3}$ coatings and sintered $\mathrm{Al}_{2} \mathrm{O}_{3}$. 


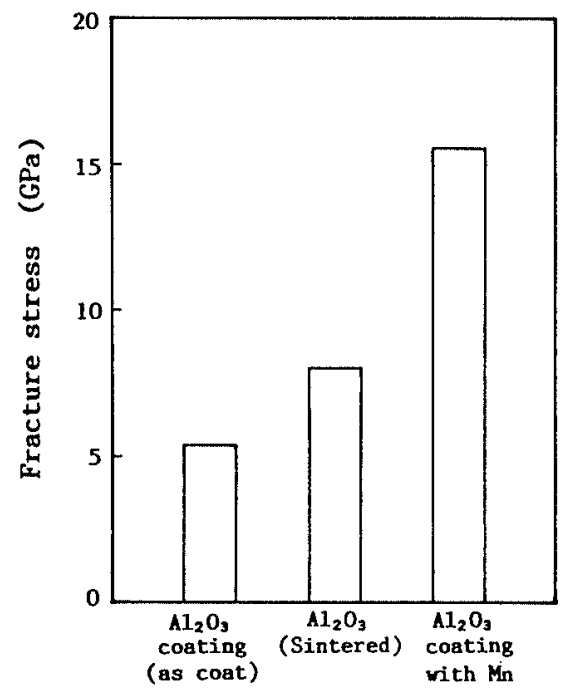

Fig. 13. Fracture stress for $\mathrm{Al}_{2} \mathrm{O}_{3}$ coatings as-sprayed, heat-treated with $\mathrm{Mn}$ and sintered alumina.

where

$$
\begin{gathered}
\sigma_{\circ}=\frac{F}{\pi a^{2}} \\
A=\frac{3 \pi(4+v)}{8(1-2 v)}
\end{gathered}
$$

$\sigma$ : maximum tensile stress; $\sigma_{\circ}$ : average stress over contact area; $F$ : applied load; $a$ : contact radius; $f$ : friction coefficient; $v$ : Poisson's ratio.

Figure 13 shows results of fracture stress calculated for $\mathrm{Al}_{2} \mathrm{O}_{3}$ coating heat-treated with $\mathrm{Mn}$ for $3.6 \mathrm{ks}$ at $1573 \mathrm{~K}$, as-sprayed $\mathrm{Al}_{2} \mathrm{O}_{3}$ coating and sintered $\mathrm{Al}_{2} \mathrm{O}_{3}$. From the figure, it is recognized that the fracture stress of $\mathrm{Al}_{2} \mathrm{O}_{3}$ coating changes from 6 to $16 \mathrm{GPa}$ after heattreatment with $\mathrm{Mn}$.

\section{Conclusion}

Liquid Mn penetration treatment for plasma-sprayed $\mathrm{Al}_{2} \mathrm{O}_{3}$ coating was studied by heating in vacuum atmosphere. Mn penetration behavior into connected porosities in coating was examined in order to improve the mechanical properties of $\mathrm{Al}_{2} \mathrm{O}_{3}$ coating. The main results obtained are as follows.

(1) The penetration of liquid $\mathrm{Mn}$ into plasmasprayed $\mathrm{Al}_{2} \mathrm{O}_{3}$ coating was recognized by heating at $1573 \mathrm{~K}$ in pressure of $1.33 \times 10^{-3} \mathrm{~Pa}$. The penetration of Mn occurred through connected porosities which are composed of micropores, a non-bonded area between $\mathrm{Al}_{2} \mathrm{O}_{3}$ particles deposited, and microcracks in individual flattened particles in $\mathrm{Al}_{2} \mathrm{O}_{3}$ coating. During $\mathrm{Mn}$ penetration, liquid $\mathrm{Mn}(\mathrm{O})$ reacted with $\mathrm{Al}_{2} \mathrm{O}_{3}$ particles to form $\mathrm{MnAl}_{2} \mathrm{O}_{4}$. $\mathrm{MnAl}_{2} \mathrm{O}_{4}$ filled up the connected porosities in $\mathrm{Al}_{2} \mathrm{O}_{3}$ coating.

(2) After heat-treatment with $\mathrm{Mn}, \mathrm{Al}_{2} \mathrm{O}_{3}$ coating became dense and the bond among flattened particles in $\mathrm{Al}_{2} \mathrm{O}_{3}$ coating strengthened. The microhardness of $\mathrm{Al}_{2} \mathrm{O}_{3}$ coatings reached about $1600 \mathrm{Hv}$ after heattreatment with $\mathrm{Mn}$.

\section{Acknowledgment}

This research is supported by the Ministry of Education, Culture and Science, through Grant-in-Aid for Scientific Research.

\section{REFERENCES}

1) Y. Arata: Spraying and Application of Ceramics, The Daily Industrial News Ltd., Japan, (1990), 19.

2) K. Miyajima, N. Nomura, Y. Harada and H. Nakahira: J. High. Temp. Soc. Jpn., 18 (1992), 307.

3) A. Ohmori, G. J. Li and Y. Arata: Thin Solid Films, 201 (1991), 241.

4) Y. Arata, A. Ohmori and C. J. Li: Trans Jpn. Weld. Res. Inst., 17 (1988), 311.

5) A. Ohmori, C. J. Li and Y. Arata: J. High. Temp. Soc. Jpn., 16 (1990), 332 